\title{
Perancangan Sistem Informasi E-Learning Berbasis Web Studi Kasus SMK Mandiri
}

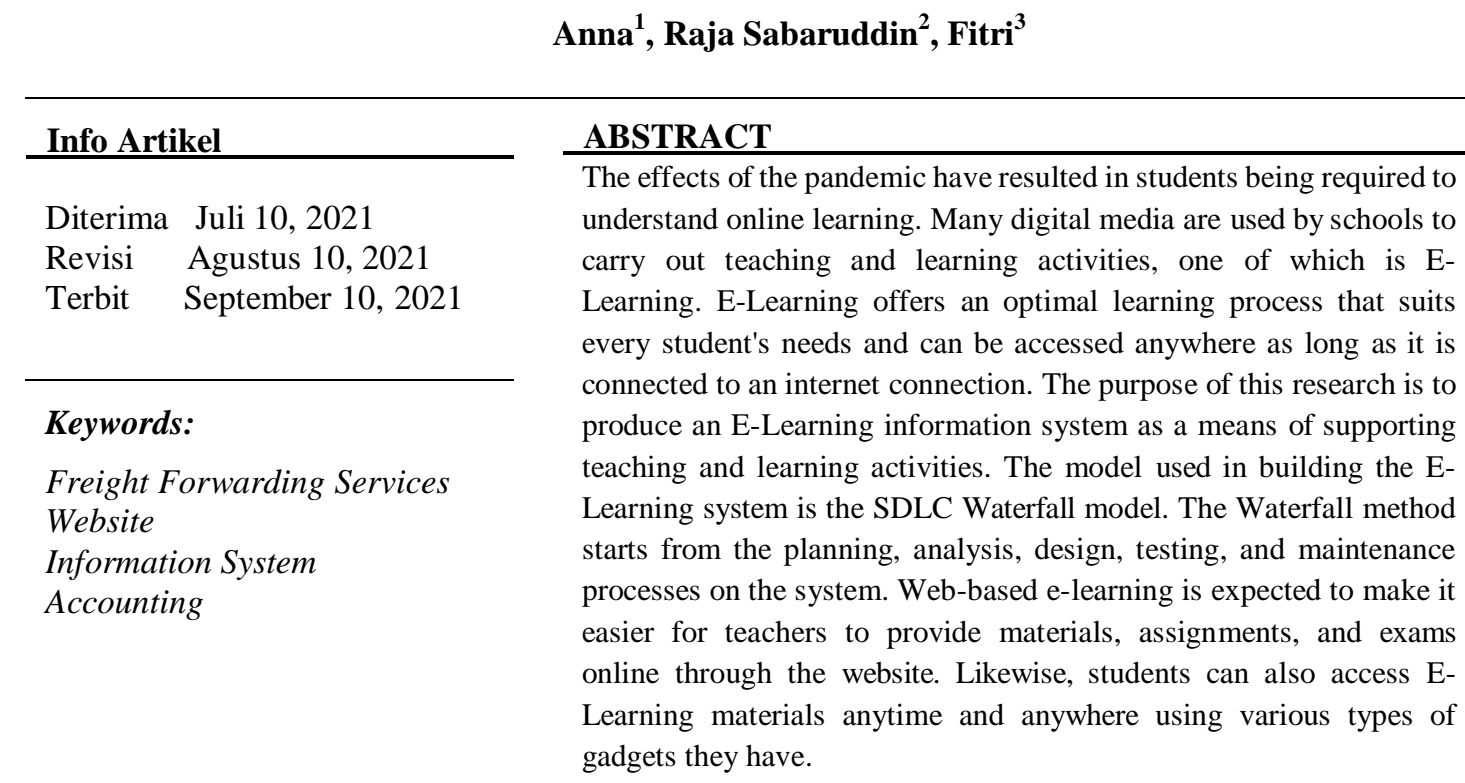

\section{Identitas Penulis:}

Anna $^{1}$, Raja Sabaruddin ${ }^{2}$, Fitri $^{3}$

Universitas Bina Sarana Informatika Kampus Pontianak

Jalan Abdurrahman Saleh no. 18 A Pontianak

Email: anna.nnz@bsi.ac.id ${ }^{1}$, raja.rjd@bsi.ac.id ${ }^{2}$, fitri15jnr@gmail.com ${ }^{3}$

\section{PENDAHULUAN}

Efek pandemi Covid-19 memberikan dampak yang besar di berbagai bidang, terutama di bidang pendidikan. Proses pembelajaran pun beralih menjadi serba online. Para pelajar dituntut untuk memahami media-media digital yang digunakan untuk mendukung kegiatan belajar mengajar. Media pembelajaran merupakan salah satu komponen sumber belajar yang penting [1]

Saat ini marak sekali banyak sekolah maupun universitas yang menyediakan fasilitas pembelajaran online berbasis website. Atau lebih dikenal dengan istilah e-Learning. E-Learning menawarkan proses pembelajaran optimal yang sesuai dengan setiap kebutuhan siswa dan bisa diakses dimana saja asalkan terhubung dengan koneksi internet. Tentunya ini menjadi solusi yang efektif ketika pandemi melanda Indonesia, dimana tidak diperbolehkan untuk sekolah tatap muka. E-learning berisi materi pelajaran yang diberikan oleh guru kepada siswa dan siswa dapat mengunduhnya dengan berbagai format, melihat teman satu kelas, melihat mata pelajaran dan mengerjakan tugas ataupun kuis. Materi pelajaran dan tugas atau kuis yang ada di dalam sistem e-learning dapat disesuaikan dengan kelas masing-masing [2]

SMK Mandiri Pontianak merupakan sekolah berbasis komputer yang tentunya sangat berperan penting untuk dapat memberikan contoh dalam pengembangan ilmu pengetahuan teknologi dan komputer. Dimasa pandemi Covid-19 ini sangat tidak memungkinkan untuk sekolah tatap muka dikarenakan takut terpaparnya virus. Peraturan pemerintah dengan menerapkan pembelajaran secara online diberlakukan oleh semua sekolah termasuk SMK Mandiri Pontianak. Awalnya media yang digunakan untuk komunikasi antara guru dan murid adalah sosial media Whatsapp untuk memberikan materi, tugas, ataupun informasi lainnya. Namun penggunaan Whatsapp Group tersebut dirasa kurang efektif untuk melaksanakan kegiatan belajar mengajar. Seperti rekap absensi para siswa satu persatu, materi belajar juga sulit untuk disampaikan karena butuh space 
memori yang besar untuk mengkases materi, tugas dan file-file lain. Serta masih beberapa lagi faktor yang membuat pembelajaran tidak nyaman apabila menggunakan media sosial tersebut. Untuk itu penelitian ini mengusulkan untuk pembuatan sistem informasi E-Learning berbasis website pada SMK Mandiri sehingga lebih memudahkan dalam kegiatan pembelajaran antara guru dan siswa.

\section{METODE}

Dalam penelitian ini digunakan metode penelitian deskriptif dan beberapa teknik pengumpulan data. Penelitian deskriptif merupakan suatu metode penelitian yang dimanfaatkan untuk menggambarkan fenomenafenomena yang ada, yang berlangsung pada saat ini atau saat yang lampau[3]. Sedangkan teknik pengumpulan data yang digunakan dalam penelitian ini yaitu observasi, wawancara dan studi pustaka.

\subsection{Metode Pengembangan Perangkat Lunak}

Penelitian ini menggunakan metode pengembangan software dengan model SDLC waterfall. Sering disebut model sekuensial linier (sequential linear). Model waterfall menyediakan pendekatan alur hidup perangkat lunak secara terurut dimulai dari analisis, desain, pengkodean, pengujian, dan tahap pendukung support. Adapun tahap-tahap yang ada di dalam model waterfall [4], yaitu:

\section{Analisis Kebutuhan Software}

Proses pengumpulan kebutuhan dilakukan secara intensif untuk mespesifikasikan kebutuhan perangkat lunak agar dapat dipahami perangkat lunak seperti apa yang dibutuhkan oleh user. Penulis melakukan analisis kebutuhan fungsional dalam perancangan sistem jasa pengiriman barang yang meliputi beranda, data customer, data penerima, data tujuan, data tarif, data transaksi, laporan transaksi, ganti password.

\section{Desain}

Desain perangkat lunak adalah proses multi langkah yang fokus pada desain pembuatan program perangkat lunaktermasuk struktur data, arsitektur perangkat lunak, representasi antarmuka, dan prosedur pengodean. Dalam tahap ini penulis menggunakan Unified Modelling Language (UML), Entity Relationship Diagram (ERD), Logical Record Structure (LRS), Activity Diagram, Sequence Diagram, Deployment Diagram, rancangan antarmuka dan pemodelan tampilan.

\section{Code Generation}

Rancangan sistem dijadikan sebagai untuk pengimplementasian atau pembuatan kode program. Penulisan kode program merupakan tahap penerjemahan desain yang dibuat kedalam bentuk perintah-perintah dengan menggunakan bahasa pemrograman. Tahapan ini penulis menggunakan Sublime Text sebagai text editor, Hypertext preprocessor (php) sebagai bahasa pemograman, phpMyAdmin sebagai media aplikasi perancangan untuk mengakses database, XAMPP-win32-7.2.3-0-VC15 sebagai aplikasi untuk menyimpan database, Apache sebagai localhost server, dan iReport sebagai pembuatan laporan.

\section{Testing}

Untuk meminimalisir kesalahan pengujian fokus pada perangkat lunak secara dari segi lojik dan fungsional dan memastikan bahwa semua bagian sudah diuji. Penulis menggunakan blacbox testing sebagai metode pengujian software dengan cara menguji halaman Website dengan menggunakan sebuah browser lalu memasukan input dan mengecek apakah output sesuai dengan yang diharapkan atau tidak.

\subsection{Website}

Konsep pemrograman web secara terurut mulai yang paling dasar sampai ke hal yang lebih kompleks. Website bisa dikatakan sebuah media informasi yang berkembang pesat sekali saat ini. Program aplikasi kini semakin banyak diminati oleh perusahaan-perusahaan. Tentunya sangat mudah untuk membangun sebuah website yang menarik dan informatif saat ini dengan menggunakan berbagai bahasa pemrograman ataupun platform khusus untuk membuat website [4].

\subsection{Sistem Informasi}

Sistem Informasi adalah sebuah sistem di dalam suatu organisasi yang mempertemukan kebutuhan pengolah transaksi harian dengan kegiatan strategi dari suatu organisasi untuk dapat menyediakan laporanlaporan yang diperlukan [4]. Sistem informasi merupakan kombinasi yang ada pada suatu organisasi yang 
mempertemukan kebutuhan pengelolaan transaksi harian, mendukung operasi, bersifat manajerial dan kegiatan strategi dari suatu organisasi dan menyediakan pihak luar tertentu dengan laporan-laporan yang dibutuhkan [5].

\subsection{E-Learning}

E-learning merupakan sebuah media yang dimanfaatkan untuk menfasilitasi pengajaran lewat teknologi elektronik internet dan sebagai transformasi proses belajar mengajar yang ada di sekolah atau universitas ke dalam bentuk digital [2]. E-learning juga sebuah proses pembelajaran jarak jauh dengan menggabungkan prinsip-prinsip dalam proses pembelajaran melalui teknologi.

Saat ini konsep E-learning sudah banyak diterima oleh masyarakat dunia, terbukti dengan maraknya implementasi di lembaga pendidikan oleh masyarakat, terbukti dengan maraknya E-Learning di lembaga pendidikan sekolah, training, universitas maupun industri seperti Cisco System, IBM, HP, dan Oracle [6]. Melalui E-Learning, proses belajar menjadi lebih fleksibel dan nyaman sehingga meningkatkan motivasi siswa untuk belajar. Siswa dapat mengakses materi pelajaran kapan pun dan di mana pun menggunakan berbagai jenis gadget yang mereka miliki. E-Learning juga memberikan kemampuan bagi guru untuk melacak kemajuan siswa dan memastikan bahwa mereka memenuhi pencapaian kinerja mereka. Dan yang tidak kalah menariknya E-Learning memungkinkan lembaga pendidikan untuk mengurangi biaya tenaga pengajar, peralatan kelas, penyewaan situs pelatihan online, dan percetakan buku[6].

\section{HASIL}

\subsection{Use Case Diagram}

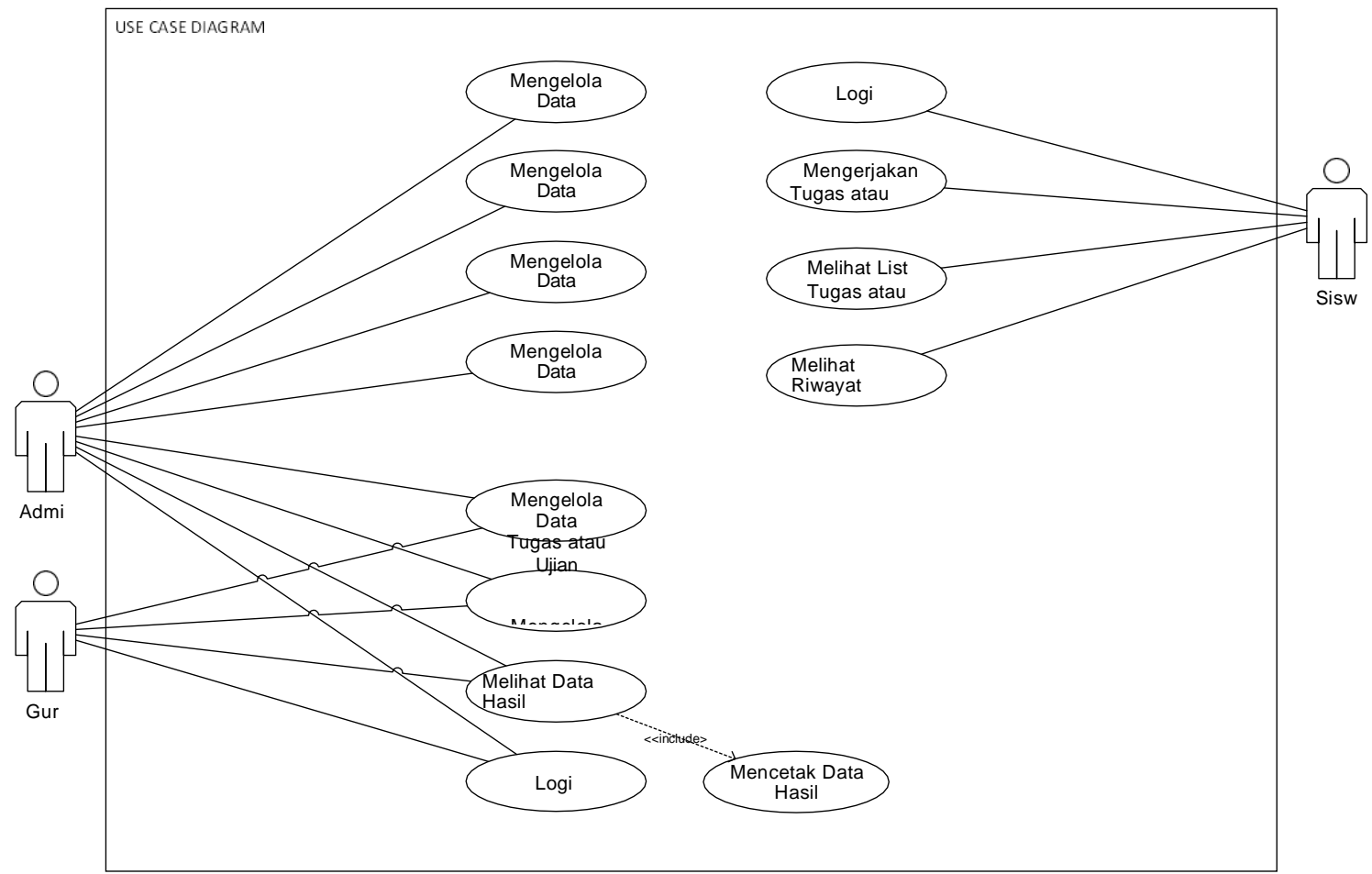

Sumber: Hasil Penelitian (2021)

\section{Gambar 1. Use Case Diagram Semua Aktor}

Pada gambar di atas dijelaskan bahwa pada website ini terdapat tiga aktor yang saling berinterkasi dengan sistem yaitu aktor guru, aktor pengelola (admin), dan aktor siswa. Masing-masing aktor memiliki tugas yang berbeda-beda. Aktor guru dapat mengelola data pelajaran, soal atau tugas, dan ujian. Aktor admin dapat mengelola data pengguna, pelajaran, data kelas, data guru, data siswa, data tugas dan ujian. Sedangkan aktor siswa hanya dapat melihat data pelajaran, mengerjakan tugas atau ujian dan melihat riwayat tugas atau ujian 
JUSTIAN, Jurnal Sistem Informasi Akuntansi

Vol. 02, No. 02, September 2021, pp. 01 11

E-ISSN: 2721-7523

\subsection{Activity Diagram}

1. Activity Diagram Login Admin dan Guru

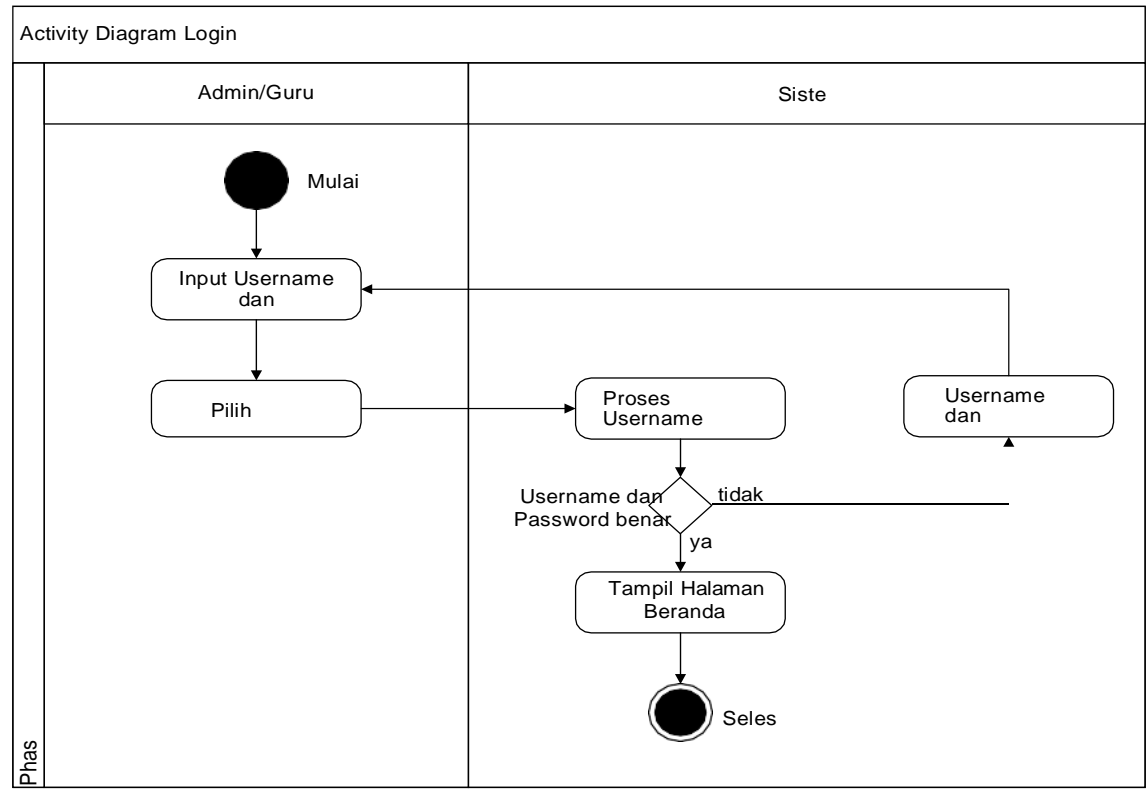

Sumber: Hasil Penelitian(2021)

Gambar 2. Activity Diagram Login Admin dan Guru

2. Activity Diagram Login Siswa

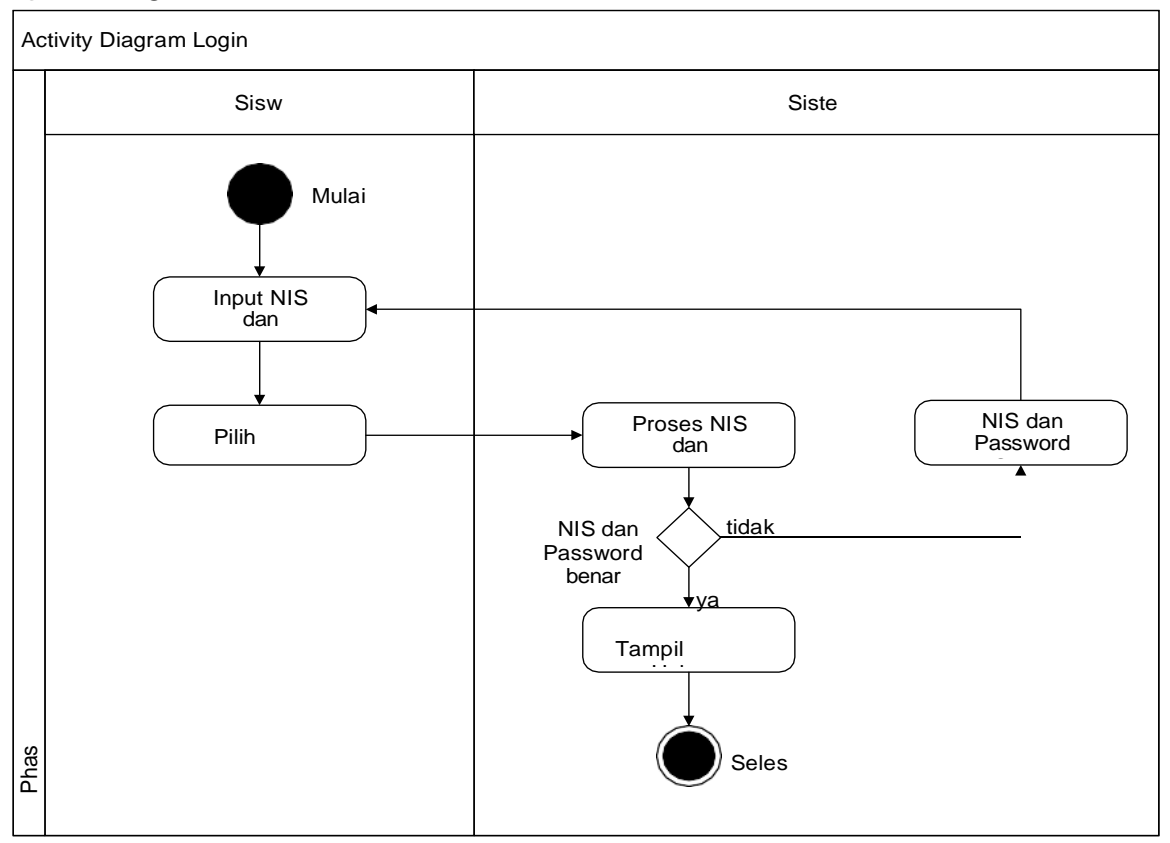

Sumber: Hasil Penelitian(2021)

Gambar 3. Activity Diagram Login Siswa 
JUSTIAN, Jurnal Sistem Informasi Akuntansi

Vol. 02, No. 02, September 2021, pp. 01 11

E-ISSN: 2721-7523

3. Activity Diagram Mengelola Data Pelajaran

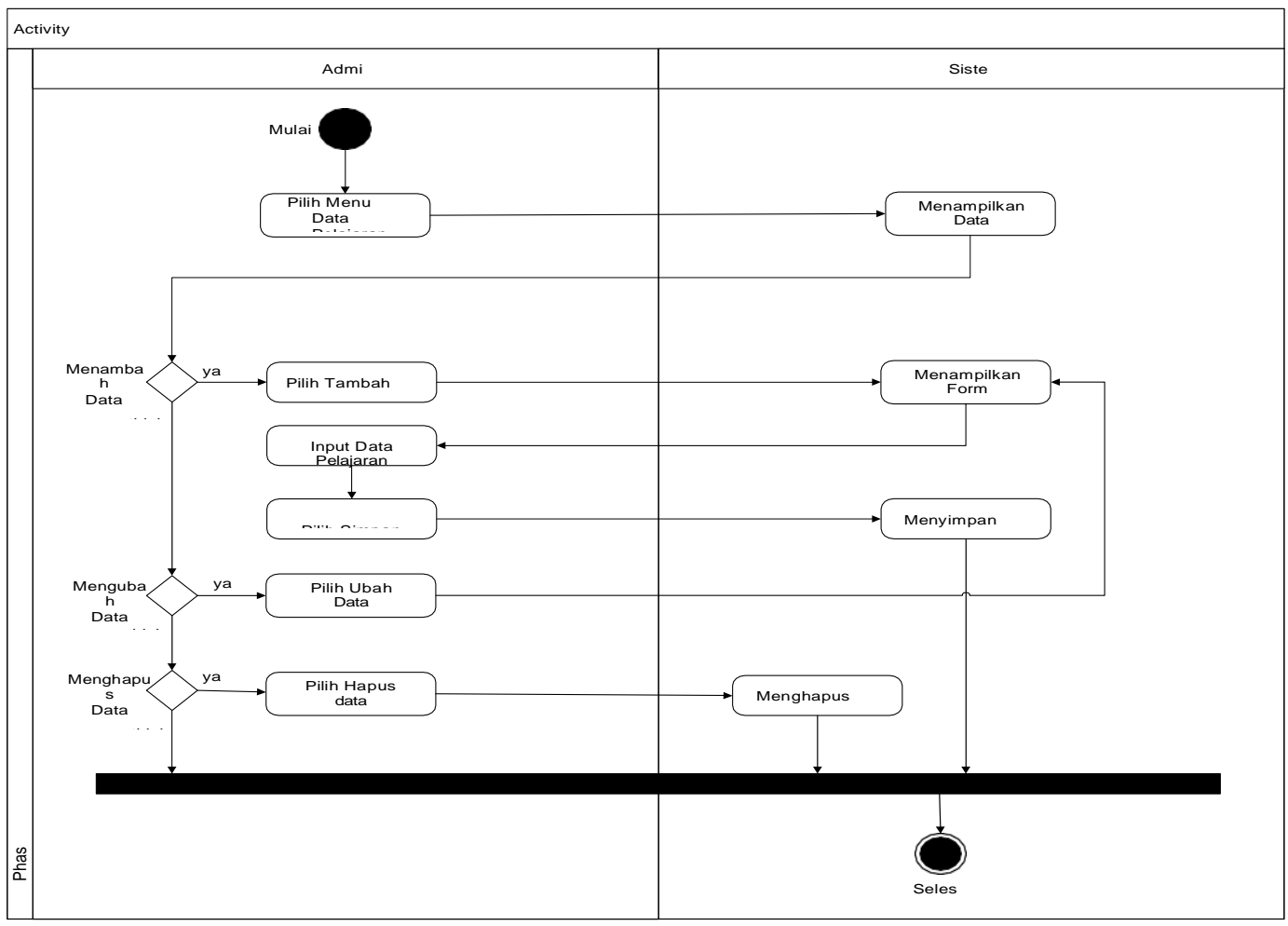

Sumber: Hasil Penelitian(2021)

Gambar 4. Activity Diagram Data Pelajaran 
JUSTIAN, Jurnal Sistem Informasi Akuntansi

Vol. 02, No. 02, September 2021, pp. 01 11

E-ISSN: 2721-7523

4. Activity Diagram Mengelola Data Siswa

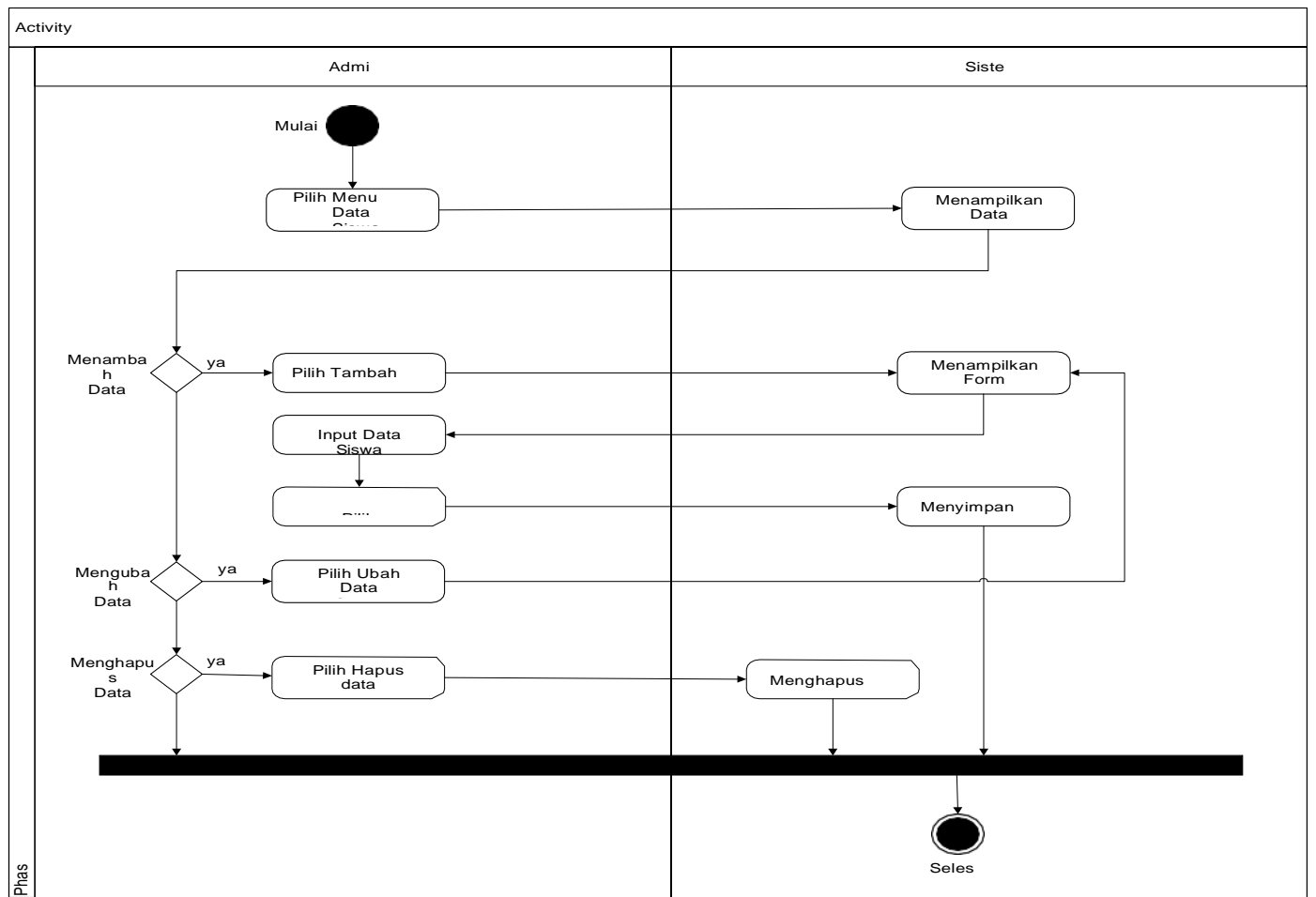

Sumber: Hasil Penelitian(2021)

Gambar 5. Activity Diagram Data Siswa

5. Activity Diagram Mengerjakan Tugas atau Ujian

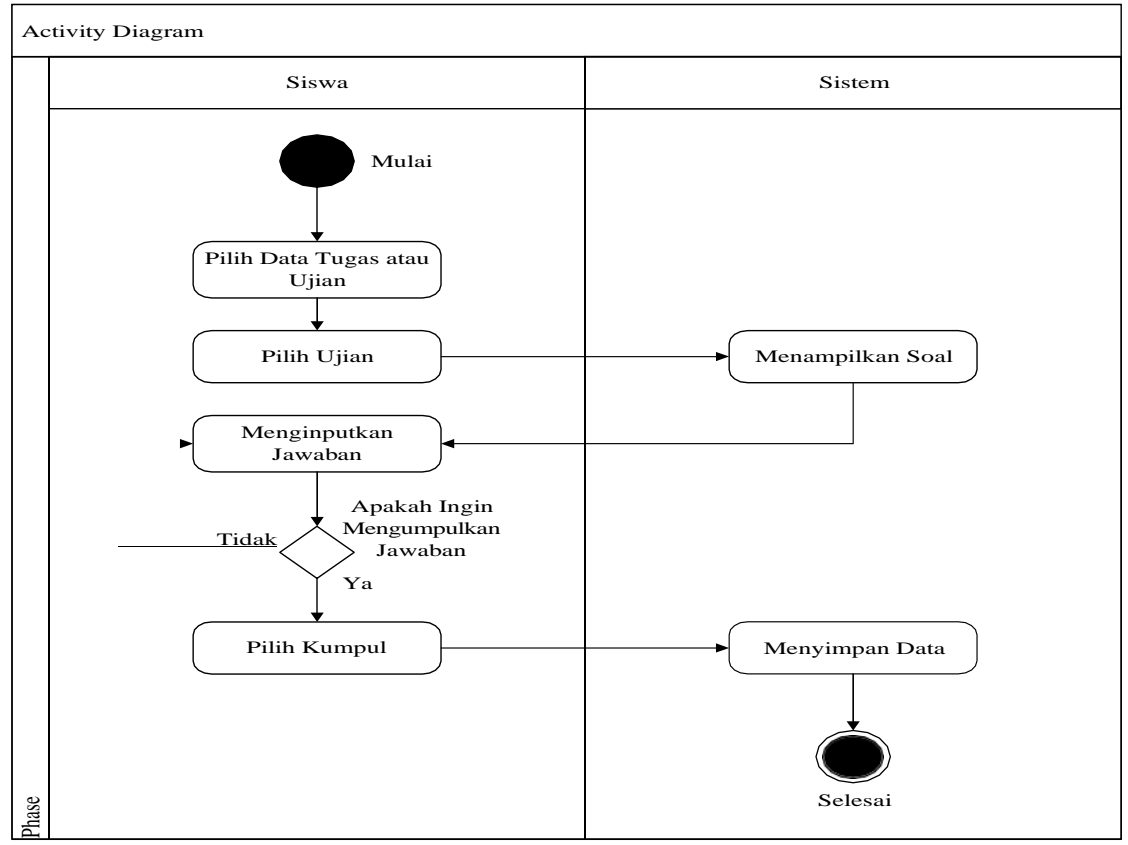

Sumber: Hasil Penelitian (2021)

Gambar 6. Activity Diagram Mengerjakan Tugas atau Ujian 


\subsection{Class Diagram}

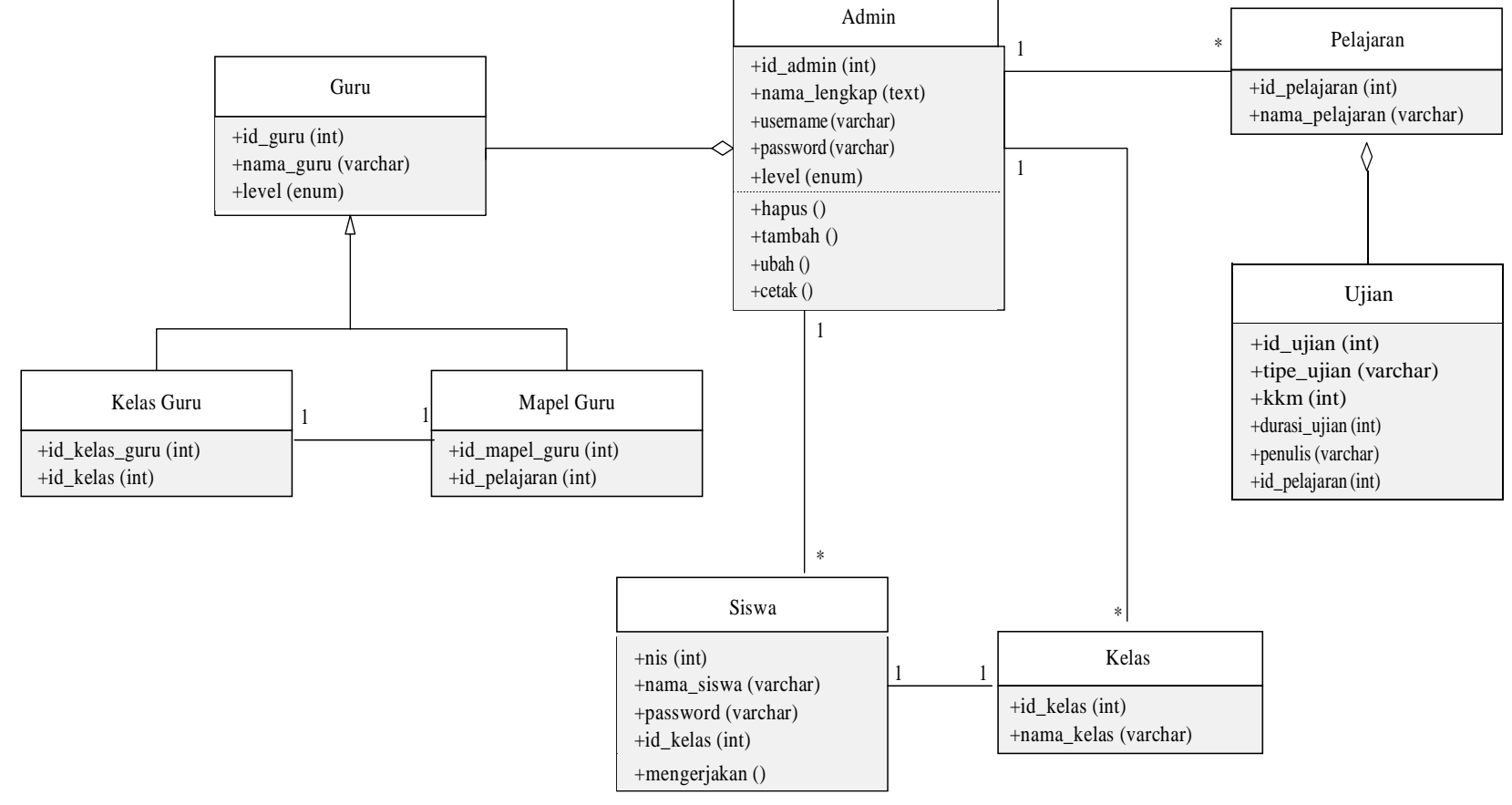

Sumber: Hasil Penelitian (2021)

\subsection{User Interface}

Gambar 7. Class Diagram Sistem Informasi E-Learning

User Interface merupakan bentuk tampilan yang berhubungan langsung dengan pengguna dan sistem operasi sehingga komputer bisa digunakan.

1. Halaman Login

Pada halaman login terdapat perbedaan antara admin/guru dan siswa. Berikut tampilannya.

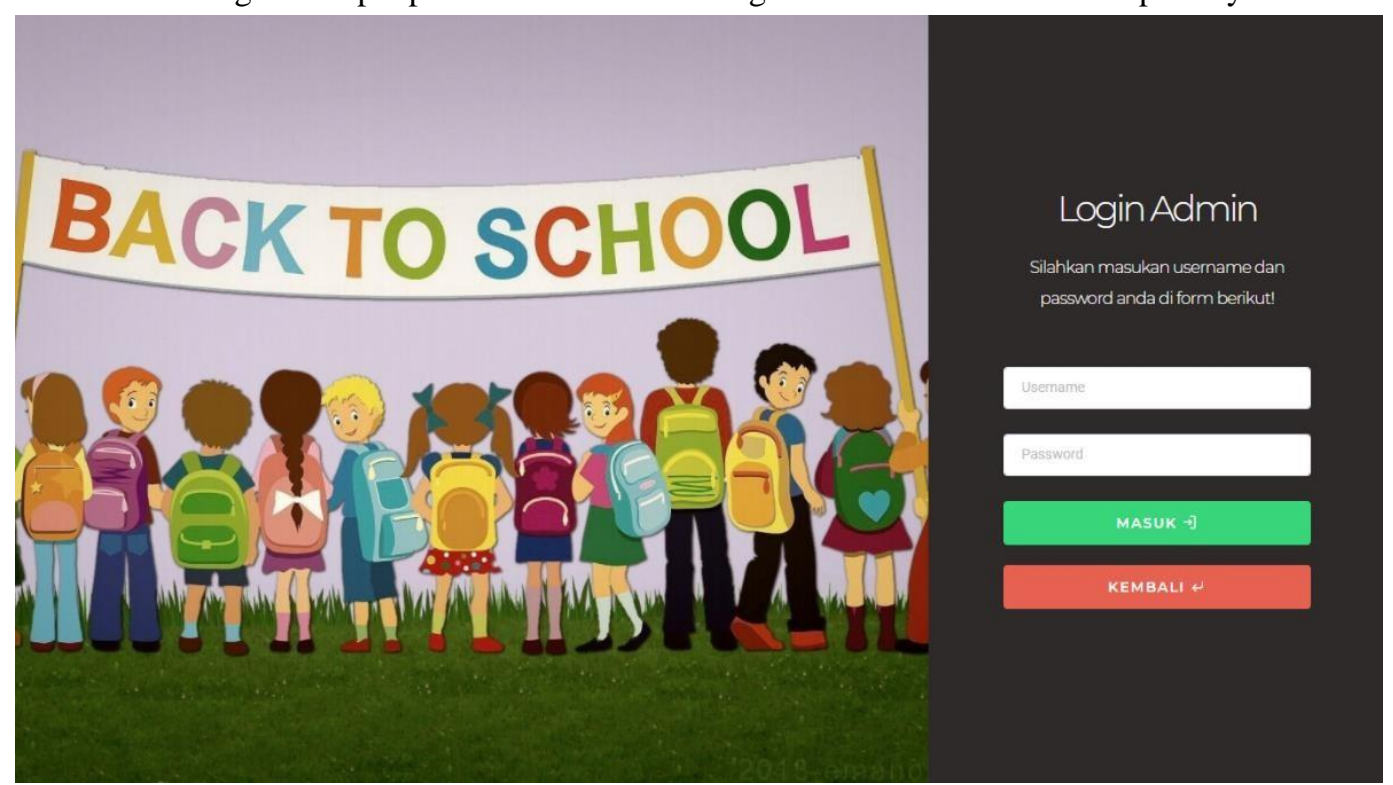

Sumber: Hasil Penelitian(2021)

\section{Gambar 8. Halaman Login Admin dan Guru}




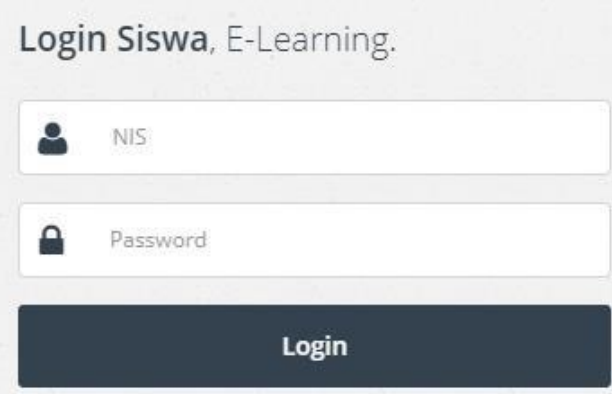

Login Sebagai Admin? Click Here

Sumber: Hasil Penelitian(2021)

2. Halaman Menu Utama

Gambar 9. Halaman Login Siswa

Pada halaman menu utama ini menampilkan menu-menu dan fitur-fitur yang ada di E-Learning. Berikut halaman untuk akses admin dan guru.

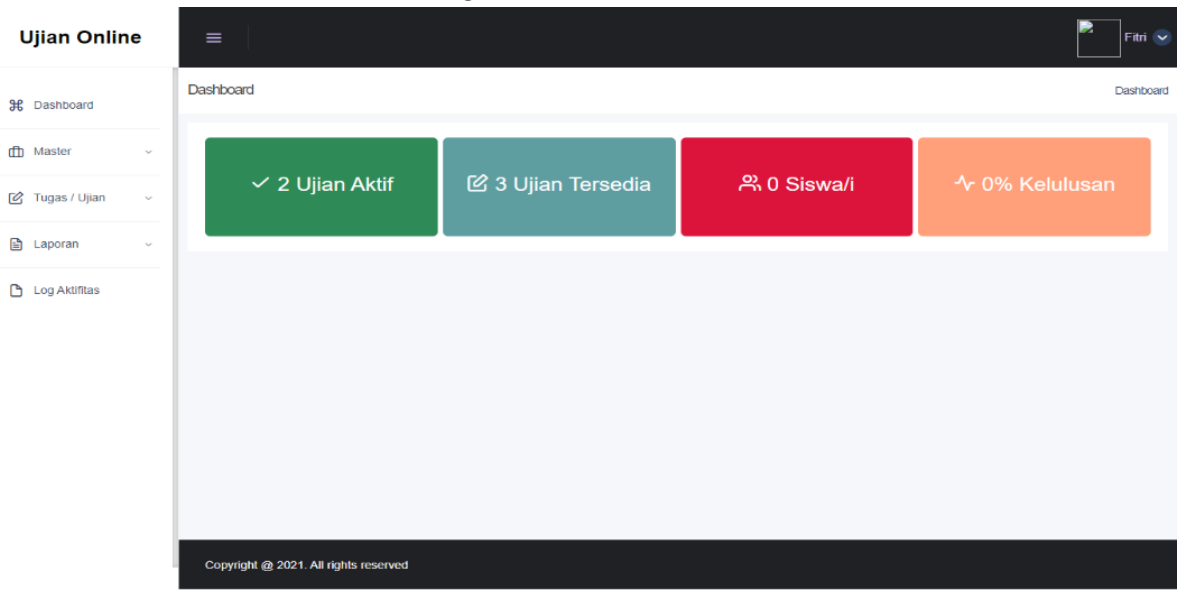

Sumber: Hasil Penelitian(2021)

Gambar 10. User Interface Halaman Menu Utama Admin dan Guru 
JUSTIAN, Jurnal Sistem Informasi Akuntansi

Vol. 02, No. 02, September 2021, pp. 01 11

E-ISSN: 2721-7523

3. Halaman Menu Pengguna

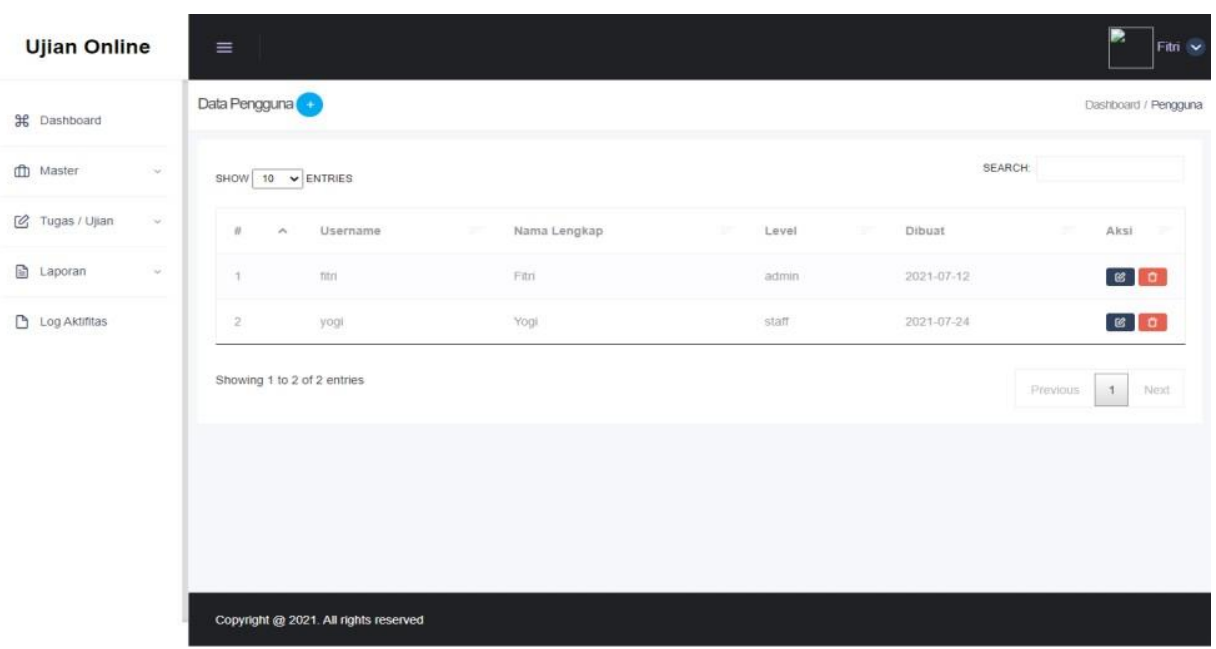

Sumber: Hasil Penelitian(2021)

Gambar 11. Halaman Menu Pengguna

4. Halaman Menu Pembuatan Soal Tugas atau Ujian

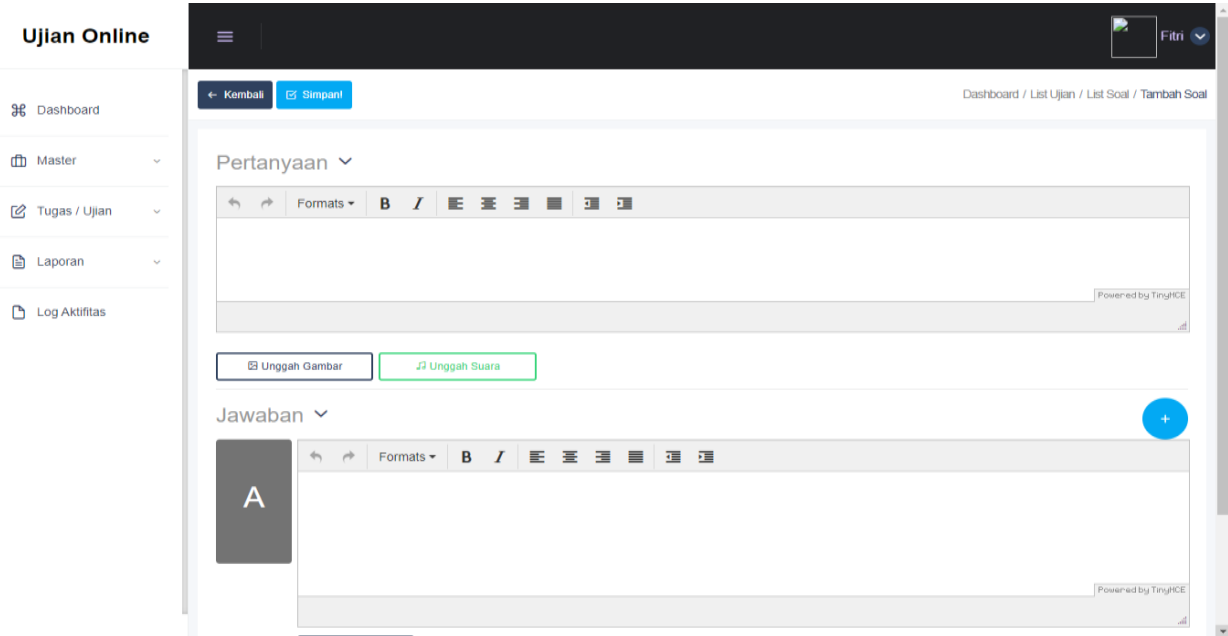

Sumber: Hasil Penelitian(2021)

Gambar 12. Halaman Menu Pembuatan Soal Tugas atau Ujian 
JUSTIAN, Jurnal Sistem Informasi Akuntansi

Vol. 02, No. 02, September 2021, pp. 01 11

E-ISSN: 2721-7523

5. Halaman Lihat Hasil Ujian

Ujian Online

If Dasnboard

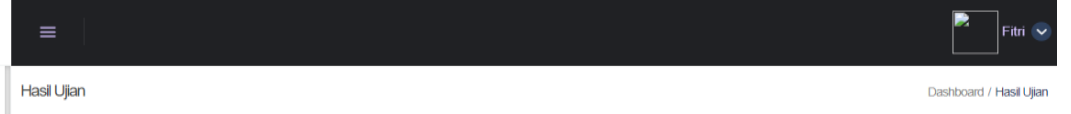

(1) Master

[e Tugas / Ujian

둡 Laporan

Q LogAktrtas

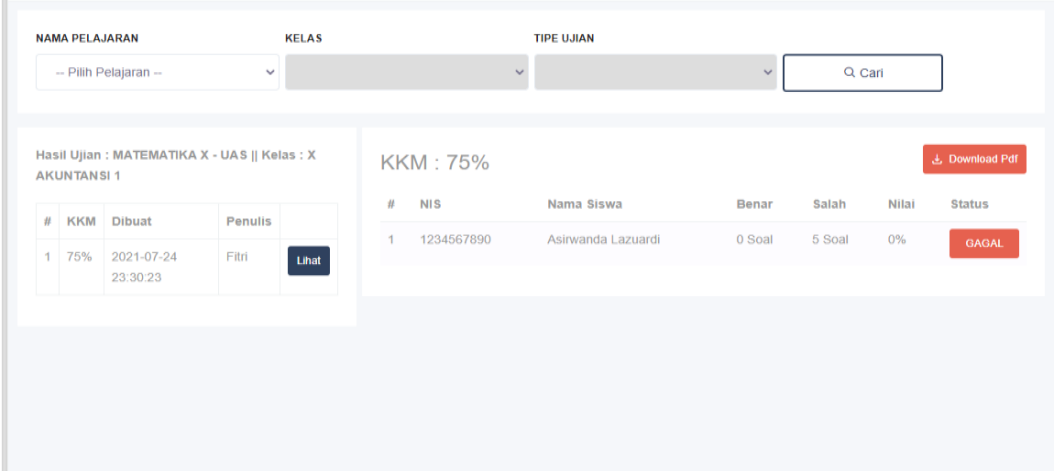

Copyright @ 1021 . All rights reserved

Sumber: Hasil Penelitian(2021)

Gambar 13. Halaman Lihat Hasil Ujian

6. Halaman Menu Ujian atau Tugas Akses Siswa

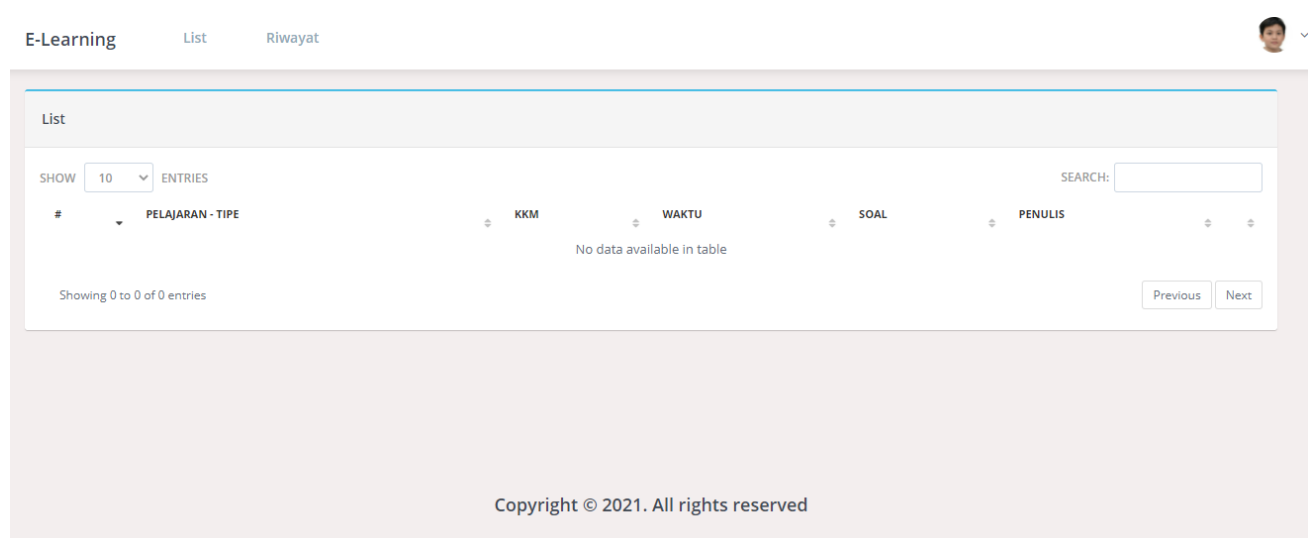

Sumber: Hasil Penelitian(2021)

Gambar 14. Halaman Menu Ujian atau Tugas Akses Siswa 


\section{KESIMPULAN}

Berdasarkan hasil penelitian ini dapat disimpulkan bahwa dengan adanya sistem informasi E-Learning ini, sangat membantu para staf dan pengajar SMK Mandiri Pontianak dalam mengelola sistem pembelajaran yang sedang berjalan secara online. Tidak hanya itu, sistem E-Learning ini juga lebih memudahkan siswa dalam mengakses materi pelajaran, tugas-tugas, maupun ujian melalui laman E-Learning ini. Untuk kedepannya diharapkan lebih banyak lagi penambahan fitur-fitur pada sistem informasi -E-Learning ini agar terciptanya suasana belajar online yang kondusif, nyaman, dan menyenangkan bagi semua pihak. Contohnya dapat ditambahkan fitur untuk presensi online ataupun ruang diskusi online untuk guru dan murid agar bisa saling berinteraksi, dan fitur-fitur lainnya.

\section{UCAPAN TERIMA KASIH}

Terima kasih kami ucapkan kepada seluruh pihak terkait atas terlaksananya penelitian ini, terutama kepada Allah swt, serta kepada pihak penerbit yang telah berkenan untuk menerbitkan paper ini.

\section{REFERENSI}

[1] T. Makmur, "Teknologi Informasi: Dampak dan Implikasi Bagi Perpustakaan, Perpustakawan, serta Pemustaka," Perpust. dan Ilmu Inf., vol. 1, no. 1, p. 65, 2019.

[2] J. Hutagalung, H. Winata, and H. Jaya, "Perancangan Dan Implementasi E-Learning Berbasis Web Pada SMA Negeri 1 Siantar," J. Teknol. Sist. Inf. dan Sist. Komput. TGD, vol. Vol 2,No 1, no. 1, p. 7, 2019, [Online]. Available: https://ojs.trigunadharma.ac.id/index.php/jsk/article/view/90.

[3] K. Handayani, "Sistem Informasi Pengelolaan Ziswaf ( Zakat, Infaq ," J. Khatulistiwa Inform., vol. VIII, no. 2, pp. $114-120,2020$.

[4] Anna, "Sistem Informasi Penjualan Dan Pembelian Obat Pada Apotek Dika Farma Pontianak Berbasis Web," J. Informatika Kaputama, vol. 5, no. 2, pp. 340-347, 2021, [Online]. Available: https://jurnal.kaputama.ac.id/index.php/JIK/article/view/571.

[5] J. Hutahaean, "Konsep Sistem Informasi," in Deepublish, 1st ed., Yogyakarta: Deepublish, 2014, p. 10.

[6] A. Jimi, "Perancangan Sistem E-Learning Berbasis Web Pada Smp N 2 Busalangga," J. Pendidik. Teknol. Inf., vol. 3, no. 1, pp. 29-37, 2020, doi: 10.37792/jukanti.v3i1.108 